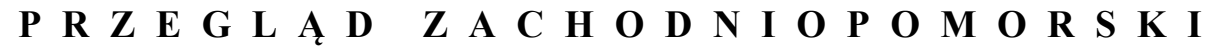 ROCZNIK XXXIV (LXIII) ROK 2019 ZESZYT 3
}

\section{$\begin{array}{lllllllll}\mathbf{A} & \mathbf{R} & \mathbf{T} & \mathbf{Y} & \mathbf{K} & \mathbf{U} & \mathbf{L} & \mathbf{Y}\end{array}$}

\author{
AleKSANDRA SKIBA \\ ORCID: 0000-0002-2270-0169 \\ Książnica Pomorska w Szczecinie \\ e-mail: a.skiba@ksiaznica.szczecin.pl
}

\section{KoRESPONDENCJA RODZINNA MARII DĄBROWSKIEJ W ZBIORACH KSIĄŻNICY POMORSKIEJ}

Słowa kluczowe: Maria Dąbrowska (1889-1965), listy polskie, życie codzienne, PRL

Keywords: Maria Dąbrowska (1889-1965), Polish letters, everyday life, Polish People’s Republic

\section{Wprowadzenie}

Zbiór epistolograficzny jest ważnym elementem każdej spuścizny rękopiśmiennej przechowywanej przez archiwum lub bibliotekę. Niejednokrotnie dostarcza szczegółowych informacji dotyczących działalności i życia twórcy, uzupełniając tym samym inne dostępne źródła. Rolę taką spełniają także listy i pocztówki nadesłane przez Marię Dąbrowską do siostry i siostrzenicy mieszkających na Pomorzu Zachodnim. Wprawdzie długoletnia korespondencja autorki Nocy $i$ dni to głównie wiadomości o charakterze ściśle prywatnym, a więc wydawałoby się mało przydatnym w świetle twórczości pisarki, jednak, jak każda kolekcja listów, jest pełnoprawnym przedmiotem badań zawierających informacje historyczne, kulturowe, literaturoznawcze czy socjologiczne. 
Z trzech płaszczyzn badawczych jakie charakteryzują list jako gatunek, a mianowicie aspektu dokumentacyjno-źródłowego, teoretycznego i opisowo-historycznego ${ }^{1}$ podjęto $\mathrm{w}$ niniejszym artykule kwestię pierwszą i ostatnią. Problemy teorii dotyczące głównie specyfiki gatunkowej korespondencji i analizy listu jako dzieła literackiego ze względu na ich literaturoznawczy charakter nie zostały wzięte pod uwagę 2 . Osobisty wydźwięk korespondencji pozwolił na zweryfikowanie informacji z zapisami w dziennikach prowadzonych przez pisarkę prze niemal całe dorosłe życie. Przydatne okazały się w tym wypadku oba wydania, a więc niepełna edycja z roku 1988 z obszernymi przypisami T. Drewnowskiego oraz publikacja z 2009 roku pod tą samą redakcją już bez komentarzy, ale w za to w pełnej wersji.

W celu uporządkowania informacji należy dodać, że archiwum Marii Dąbrowskiej zostało umieszczone w Muzeum Literatury im. Adama Mickiewicza w Warszawie, w tym bogata korespondencja Marii Dąbrowskiej kierowana do matki - Ludomiry Szumskiej, męża - Mariana Dąbrowskiego, długoletniego partnera - Stanisława Stempowskiego oraz przyjaciółki i partnerki - Anny Kowalskiej³. Obok tych wielotomowych jednostek swoje miejsce znalazły też listy do przyjaciół, krewnych oraz wydawnictw. Zbiory muzeum uzupełniają pisane do wielu przyjaciół i rodziny listy przechowywane w placówkach zagranicznych oraz w innych polskich instytucjach $^{4}$, a wśród nich Książnicy Pomorskiej. Kolekcja, która znalazła swoje miejsce w szczecińskiej bibliotece nie była do tej pory obiektem uwagi badaczy, a powstały przyczynek być może przybliży charakter i specyfikę prezentowanego zbioru.

1 Podział wg K. Cysewski, Teoretyczne $i$ metodologiczne problemy badań nad epistolografia, „,Pamiętnik Literacki” 1997, nr 1, s. 95.

2 Problematykę tę podejmują m.in: S. Skwarczyńska, Teoria listu, Lwów 1937 (nowe wydanie: oprac. E. Feliksiak, M. Leś, Białystok 2006); S. Skwarczyńska, Wokót teorii listu, w: Pomiędzy historia a teoria literatury, red. S. Skwarczyńska, Warszawa 1975, s. 187-197; A. Kałkowska, Wprowadzenie w problemy językowej spójności listu, „Polonica” 1978, t. 4, s. 51-71; A. Kałkowska, Struktura składniowa listu, Wrocław 1982; K. Cysewski, Wokót teorii listu: bez paradoksów, w: Genologia i konteksty, red. C.P. Dudka, Zielona Góra 2000, s. $125-132$.

3 Katalog rękopisów Muzeum Literatury im. Adama Mickiewicza w Warszawie. T. 5 , Sygnatury 2001-2180: archiwa Marii Dabrowskiej, Anny Kowalskiej, Stanisława Stempowskiego, oprac. i red. S. Kordaczuk, Warszawa 2017.

4 Jako przykład mogą posłużyć archiwa Kazimierza Wierzyńskiego i Stanisława Sułkowskiego przechowywane w Polskiej Bibliotece w Londynie oraz zbiory Burgerbibliothek w Bernie, gdzie znajduje się spuścizna Jerzego Stempowskiego. Biblioteka Uniwersytecka w Warszawie zakupiła między innymi listy do Wandy Dąbrowskiej, Ludomiry Szumskiej i Stanisława Stempowskiego. Miejska Biblioteka Publiczna im. M. Dąbrowskiej dysponuje listami adresowanymi do Heleny Hepke i Danuty Hepke-Kelch. 


\section{Adresatki korespondencji}

Helena z domu Szumska (1891-1969) to młodsza o dwa lata siostra Marii Dąbrowskiej, która wyszła za mąż za Stanisława Hepkego (1889-1964). Oboje zajmowali się pracą na roli, a Stanisław pełnił funkcję dzierżawcy lub zarządcy majątkus. Mimo częstych zmian miejsca zamieszkania - mąż Heleny radził sobie z działalnością zawodową ze zmiennym szczęściem - obie siostry miały regularny kontakt, a Maria Dąbrowska chętnie odwiedzała rodzinę Hepków ${ }^{6}$. We wspomnieniach o matce, Danuta Hepke-Kelch zanotowała, że to właśnie Helena posłużyła autorce Nocy i dni do stworzenia postaci Emilki, młodszej córki Barbary i Bogumiła Niechciców. Alter ego pisarki stała się Agnisia, najstarsze dziecko tej pary? Wyznanie to wskazuje, jak kształtował się stosunek pisarki do młodszej siostry. Wyraziły go także listy Marii, dla której Helena na zawsze pozostała młodszą, a więc wymagającą opieki siostrą.

Danuta Hepke-Kelch (1914-2004) to nie tylko siostrzenica, ale także chrześniaczka Marii Dąbrowskiej. Wychowywana w kolejnych majątkach zarządzanych przez rodziców zdała maturę w Miejskim Gimnazjum w Toruniu w roku 1933 i rozpoczęła studia na filologii klasycznej, którą jednak zostawiła, przenosząc się na polonistykę. Nauki na Uniwersytecie Warszawskim nie zdążyła ukończyć przed wojną i dopiero w 1967 roku uzyskała magisterium w Poznaniu. Siostrzenica Marii Dąbrowskiej interesowała się bibliotekoznawstwem, dlatego ukończyła w czerwcu 1939 roku Jednoroczną Koedukacyjną Szkołę Bibliotekarstwa przy Bibliotece Publicznej m.st. Warszawy. Dzięki uzyskanemu wykształceniu mogła pracować w filii przy ul. Chmielnej w Warszawie, a w 1944 roku zorganizować bibliotekę w Radzyniu Podlaskim, gdzie po roku została kierownikiem. Okres powojenny to przede wszystkim czas pracy w szkole, w której uczyła języka polskiego i francuskiego, ale także działalności bibliotecznej w Grodzisku i Bytowie. Swoją wędrówkę zakończyła w 1951 roku przenosząc się na stałe do Choszczna, gdzie przez 23 lata pełniła funkcję kierownika Biblioteki Publicznej, czynnie angażując się w życie miasta9.

5 M. Dąbrowska, Dzienniki. T. 1, wybór, wstęp i przypisy T. Drewnowski, Warszawa 1988, s. 83.

${ }^{6}$ D. Kelch, Wspomnienia siostrzenicy Marii Dąbrowskiej, Kalisz 2013, s. 11-14.

7 T. Krawiec, Siostrzenica stynnej Marii, „Gazeta Lubuska” 2003, nr 219, s. 7.

8 D. Kelch, Wspomnienia siostrzenicy..., s. 7.

9 T.W. Jabłecki, Danuta Hepke-Kelch: z cyklu zastużeni ludzie Choszczna, „Bibliotekarz Zachodniopomorski” 1997, nr 1-2, s. 63. 
Zasługą Danuty Hepke-Kelch było powołanie Koła Stowarzyszenia Bibliotekarzy Polskich w rodzinnej miejscowości, przeniesienie biblioteki do wyremontowanego Barbakanu oraz nadanie 26 kwietnia 1976 roku tej placówce imienia Marii Dąbrowskiej. Dzięki siostrzenicy przyszła patronka odwiedziła Choszczno w 1954 roku. Zasłużona bibliotekarka została doceniona za swoją pracę i zaangażowanie, a wśród wielu odznaczeń i medali otrzymała także w 2001 roku Złoty Ekslibris z rąk dyrektora Książnicy Pomorskiej, Stanisława Krzywickiego ${ }^{10}$.

\section{Charakterystyka formalna korespondencji}

Listy Marii Dąbrowskiej do Heleny Hepke i Danuty Hepke-Kelch stały się częścią zespołu archiwalnego zawierającego trzy jednostki ${ }^{11}$, a w jego nazwie wykorzystano tylko nazwisko siostrzenicy pisarki, ponieważ:

- adresatki korespondencji to naprzemiennie matka lub córka, które nie mieszkały razem, ale tematy podejmowane przez nadawczynię omawiane były równolegle,

- w kolekcji znalazły się fotografie Danuty Hepke-Kelch,

- ostatnią właścicielką archiwum rodzinnego była siostrzenica pisarki.

$\mathrm{Na}$ spuściznę złożył się niewielki dar Miejskiej Biblioteki Publicznej w Choszcznie z 2001 roku oraz zakup z tego samego okresu przeprowadzony w dwóch transzach. Nabyte od Danuty Hepke-Kelch dokumenty stały się własnością Książnicy Pomorskiej dzięki wsparciu Telekomunikacji Polskiej, Stowarzyszeniu Bibliotekarzy Polskich, Koła nr 1 przy Książnicy Pomorskiej w Szczecinie oraz osób prywatnych - Zofii i Longina Komołowskich. Szczeciński działacz był w tym okresie wiceprezesem Rady Ministrów oraz ministrem polityki społecznej i pracy, dlatego informacja o sfinansowaniu części zbioru była długi czas nienagłaśniana $^{12}$. W archiwum obok listów Marii Dąbrowskiej, stanowiących główny trzon kolekcji, umieszczono fotografie (trzy z nich to wspomniany dar biblioteki w Choszcznie) oraz korespondencję osób różnych, między innymi Ludomiry Szu-

\footnotetext{
${ }^{10}$ A. Kościuczuk, Danuta Maria Kelch z domu Hepke, „Bibliotekarz Zachodniopomorski” 2013, nr 4, s. 22-23.

${ }^{11}$ Korespondencja Marii Dąbrowskiej do Heleny Hepke i Danuty Hepke-Kelch [rękopis], Książnica Pomorska w Szczecinie, nr sygn. Rkps986; Korespondencja osób różnych do Heleny Hepke i Danuty Hepke-Kelch [rękopis], KP, nr sygn. Rkps987; Fotografie rodzinne ze zbiorów Danuty Hepke-Kelch [rękopis], KP, nr sygn. Rkps988.

${ }^{12}$ Akcesje. Nr 2, lata 1998-2005, Książnica Pomorska, Dział Zbiorów Specjalnych, Oddział Starych Druków i Rękopisów, Sekcja Rękopisów, k. 191-192, 207-208.
} 
mskiej i Anny Kowalskiej, do Heleny. Przyjaciółka Dąbrowskiej pisała do siostry pisarki przede wszystkim o stanie zdrowia Marii, a po jej śmierci informowała o decyzjach w sprawie spuścizny i kwestii testamentów pozostawionych przez autorkę Przygód Człowieka myślacego.

W jednostce zawierającej korespondencję pisarki złożono 35 listów, 27 pocztówek i 7 kart pocztowych przesłanych do Heleny Hepke oraz 14 listów, 3 pocztówki i kartę pocztową adresowanych do Danuty Hepke-Kelch. W woluminie znalazł swoje miejsc także list przesłany do Stanisława Hepkego, który jesienią 1962 roku przebywał w szpitalu (list, 8.11.1962). Na jednostkę złożyło się więc łącznie 87 dokumentów, w tym 50 listów, 30 pocztówek i 8 kart pocztowych.

Korespondencję rozpoczęła, datowana na podstawie stempla pocztowego, pocztówka wysłana w 1934 roku, a ostatni list (25.03.1965) pisarka wysłała ze szpitala niecały miesiąc przed śmiercią. 31 lat to niewątpliwie imponujący okres w wypadku nieprzerwanej korespondencji, jednak w sytuacji Marii Dąbrowskiej i Heleny Hepke rok 1934 na pewno nie odpowiadał rzeczywistości. Opuszczając dom rodzinny na początku XX wieku, siostry musiały nawiązać kontakt listowny znacznie wcześniej. Wprawdzie Maria odwiedzała Helenę dość regularnie, a więc korespondencja mogła być niepotrzebna, jednak wizyty wiązały się przede wszystkim z okresem letnim, kiedy także matka, Ludomira i siostra obu pań, Jadwiga przyjeżdżały na wakacyjny wypoczynek ${ }^{13}$. Analiza dat dokumentów przechowywanych w Książnicy Pomorskiej także potwierdziła ten wniosek. Korespondencja $\mathrm{z}$ lat 30 . i pierwszej połowy lat 40 . XX wieku to tylko 3 karty pocztowe, podczas gdy pozostałe 84 dokumenty wysłano już w latach powojennych. Kolejny argument to duża dysproporcja w wymianie listów zauważona w korespondencji Heleny i Danuty, a skierowanych do Marii Dąbrowskiej. Kolekcja 748 listów siostry pisarki z lat 1912-1965 oraz 103 listy siostrzenicy, która korespondencję rozpoczęła w 1922 roku $^{14}$, sugerują brak pokaźnej liczby dokumentów wśród tych przekazanych szczecińskiej bibliotece. Wprawdzie Maria Dąbrowska nie musiała odpowiadać na wszystko, mogła także odpisywać nieregularnie, jednak znając jej zamiłowanie do porządkowania i przechowywania całej korespondencji oraz do epistolografii ${ }^{15}$ trudno zakładać, że wymiana infor-

${ }^{13}$ D. Kelch, Wspomnienia siostrzenicy..., s. 9, 11.

${ }^{14}$ Listy Heleny Hepke do Marii Dąbrowskiej [rękopis], MLit., nr sygn. 2060; Listy do Marii Dąbrowskiej od siostrzenicy, Danuty Kelch z domu Hepke [rękopis], MLit., nr sygn. 2062.

${ }^{15}$ E. Głębicka, Dąbrowska (nie)znana: szkice, Warszawa 2013, s. 388-389. 
macji z bliskimi przedstawiała się w wyżej wymienionym okresie tak skromnie. Należy założyć, że dokumenty z okresu dwudziestolecia międzywojennego i czasów II wojny światowej nie zachowały się, co mogło wynikać przede wszystkim z niezwykłej mobilności rodziny Hepków. Do 1949 roku — momentu osiedlenia się w Choszcznie - małżeństwo dziewięciokrotnie zmieniło miejsce pobytu ${ }^{16}$, natomiast trzon zbioru to korespondencja z lat 50. i 60. XX wieku. Wyraźnie widać, że decyzja o zamieszkaniu na stałe w pomorskiej miejscowości, mimo późniejszej zmiany lokum (list, 20.08.1964) zdecydowanie ułatwiła gromadzenie i przechowywanie listów od sławnej krewnej.

Szczególnym suplementem do opisywanego zespołu archiwalnego stały się korespondencja pisarki i rękopiśmienne wspomnienia Danuty Hepke-Kelch, dostępne dzięki Zachodniopomorskiej Bibliotece Cyfrowej „Pomerania”"17. Właścicielem zdigitalizowanego na początku tego roku zbioru, stała się Biblioteka Publiczna w Choszcznie. Na kolekcję złożyło się 6 listów oraz 3 karty pocztowe, z których kilka podarowanych zostało $\mathrm{w}$ dniu przyjęcia przez bibliotekę imienia patronki - Marii Dąbrowskiej. Kolejna część trafiła do placówki już po śmierci właścicielki. Listy, wraz z pamiątkami po choszczeńskiej działaczce, zostały odnalezione przez emerytowane bibliotekarki - Zofię Gołofit-Sobacką i Teresę Antoniewicz w mieszkaniu zmarłej, a następnie przekazane bibliotece ${ }^{18}$. Zeskanowane dokumenty stały się integralną częścią zbioru szczecińskiego, zostały więc wzięte pod uwagę podczas analizy treściowej.

\section{Charakterystyka rzeczowa korespondencji}

Listy i karty pocztowe Marii Dąbrowskiej to typowy przykład zachowania powszechnie używanych form epistolograficznych. Nadawczyni z nielicznymi wyjątkami (pocztówka, 1934; list, 21.07.1957) umieszczała nazwę miejscowości,

\footnotetext{
${ }^{16}$ Danuta Hepke wymienia w swych wspomnieniach następujące miejscowości: Glina (powiat otwocki), Płonne (powiat golubsko-dobrzyński), Dominów (powiat lubelski), Raczyn (rejon horochowski, Ukraina), Morsk (powiat świecki), Niszczewice (powiat inowrocławski), Wola Ossowińska (powiat radzyński), Piaski (osiedle Grodziska Wielkopolskiego), Choszczno (gmina Choszczno). Podczas wojny przez pewien czas rodzina mieszkała także w Warszawie u siostry Stanisława Hepkego.

${ }^{17}$ Maria Dąbrowska: wspomnienia siostrzenicy [dokument elektroniczny], KP, nr sygn. MW131; Korespondencja Marii Dąbrowskiej do Heleny Hepke i Danuty Hepke-Kelch [dokument elektroniczny], KP, nr sygn. MW132.

${ }^{18}$ Informacje pochodzą z korespondencji mailowej Aleksandry Skiby z Anna Lewicką, dyrektorką Miejskiej Biblioteki Publicznej w Choszcznie z 22.03.2019.
} 
gdzie wówczas przebywała i datę dzienną (czasami także dzień tygodnia), zawsze rozpoczynała od formy grzecznościowej w postaci nagłówka Droga lub Kocha$n a$, dziękowała też za otrzymaną korespondencję. W podziękowaniach zwykle widoczne było zaangażowanie pisarki, która nie tylko przepraszała za spóźnione odpowiedzi (list, 25.12.1953) i informowała o otrzymanej korespondencji (karta pocztowa, 21.05.1964), ale martwiła się, jeżeli sama długo nie dostawała wiadomości zwrotnej (list, 22.08.1958) i dopytywała o liczbę listów, które dotarły do adresatek (list, 3.01.1957). Zakończenie było także konwencjonalne, tak więc odbiorczynie otrzymywały pozdrowienia, pod którymi umieszczony był podpis w postaci całego imienia i nazwiska, imienia i pierwszej litery nazwiska, pierwszej litery imienia lub krótkie - Maryjka. Forma ostatnia to zdrobnienie używane w kręgu rodzinnym ${ }^{19}$ i środowisku literackim, które Dąbrowska wykorzystywała, podpisując swoją korespondencję do rodziny przede wszystkim w ostatnim okresie życia. Na cały zbiór złożyły się 82 rękopisy i 5 maszynopisów z rękopiśmiennym dopiskiem $\mathrm{w}$ postaci krótkich pozdrowień oraz podpisu. Charakter pisma niezbyt staranny, jednak w miarę regularny, nie przysparzał prawdopodobnie większych trudności podczas lektury. Rozchwianie i niepewność w stawianiu liter widać tylko $\mathrm{w}$ nielicznych dokumentach, ale $\mathrm{z}$ reguły były to listy pisane w pośpiechu (list, 8.08.1954) w trakcie choroby (list, 24.08.1960) lub w okresie rekonwalescencji (list, 29.03.1957), natomiast najwymowniejszym świadectwem osłabienia sił witalnych stanowi tekst wysłany na miesiąc przed śmiercią (list, 25.03.1964).

W treści dokumentów zwraca uwagę aktywność autorki Nocy $i$ dni, z jaką angażowała się w rozwiązywanie problemów krewnych. W każdym liście wysłanym zarówno do Heleny, jak i do Danuty pisarka poruszała kwestie finansowe, martwiąc się o rodzinę Hepków. Regularnie informowała o wysokości i liczbie wysłanych przekazów pieniężnych. Czasem obok stałych zapomóg proponowała też dodatkowe wsparcie, jak w przypadku kłopotów odzieżowych Heleny, której zaoferowała swój płaszcz (list, 11.08.1958). Najwięcej miejsca zajmowały jednak kwestie rodzinne, takie jak śluby, narodziny dzieci, choroby i odejścia bliskich, przy czym najbardziej osobisty jest list informujący o śmierci Stanisława Stempowskiego (list, 20.01.1952).

Informacje z kręgu rodzinnego uzupełniają liczne i szczegółowe wskazówki, których Maria Dąbrowska nie skąpiła swoim adresatkom, przy czym

${ }^{19}$ D. Kelch, Wspomnienia siostrzenicy..., s. 7. 
skala problemów wahała się od spraw błahych po kwestie absolutnie poważne. W związku z tym dokładnie poinstruowała Helenę, w jaki sposób zakupić bilet kolejowy w wagonie sypialnym (list, 15.01.1957), by znowu Danucie wyjaśnić, przy okazji swojej podróży do Chorwacji, termin pieta (karta pocztowa, 16.04.1936). Informacje miały ułatwić siostrze wizytę w Warszawie, a w wypadku chrześniaczki poszerzyć jej wiedzę ogólną, zastanawia jednak celowość podobnych uwag, szczególnie w przypadku Danuty. Wprawdzie znaczenie wyrazu pieta nie musiało być w latach 30 . XX wieku powszechnie znane, ale wydaje się, że w przypadku studentki kierunku humanistycznego, jaką była w tym czasie siostrzenica Dąbrowskiej, tego rodzaju wyjaśnienie były raczej zbędne. W podobny sposób zareagowała pisarka, dowiadując się o chorobie Stanisława Hepkego. Koncentrując się na stanie zdrowia szwagra, wypowiedziała się na temat choszczeńskiego szpitala, sposobów przetaczania krwi oraz czynności, które, jej zdaniem, powinny podjąć matka i córka (list, 28.09.1962).

Troskliwość pisarki, która popada momentami w ton mentorski, wynikała prawdopodobnie z nadmiernego niepokoju o bliskich. Maria Dąbrowska swoje listy kierowała do młodszej siostry, a więc jako najstarsza z rodzeństwa mogła cały czas czuć się odpowiedzialna. Podobny stosunek miała też do młodszej o generację siostrzenicy, co potwierdziła zresztą sama Danuta Hepke-Kelch w jednym z wywiadów, podkreślając, że pisarka traktowała ją zawsze jak córkę ${ }^{20}$. Dowodów oddania rodzinie dostarczała też sama Dąbrowska, pisząc w swoim dzienniku między innymi o operacji oczu, jakiej poddała się jej siostrzenica w latach 30 . bez wiedzy matki, a za zgodą i przy poparciu pisarki. Autorka Nocy i dni relacjonując całą sytuację, niejako przy okazji ujawniła jakim wsparciem była dla chrzestnej córki oraz, w sposób mniej oczywisty, także i dla Heleny, której z obawy przed wybuchem „histerii” o niczym nie poinformowała (dzienniki, 4.09.1936). Stos unek Marii do siostry nie oznaczał jednak uległości ze strony tej drugiej, co także znalazło odbicie w korespondencji. W jednym z listów autorka Przygód człowieka myślacego obszernie usprawiedliwiła swoje postępowanie w związku z artykułem Marii Szypowskiej ${ }^{21}$, w którym pojawiło się nazwisko rodowe matki ${ }^{22}$. Dąbrowska

${ }^{20}$ Zainteresowanie pisarki było stałe i trwało całe życie, o czym świadczą słowa Danuty Hepke-Kelch, która w jednym z wywiadów wspomina o comiesięcznej kwocie, jaką przed wojną chrzestna matka wysyłała na książeczkę oszczędnościową, myśląc o przyszłości siostrzenicy. E. Lipińska, Tu żyją potomkowie Niechciców, „Głos Szczeciński” 2002, nr 296, s. II.

${ }^{21}$ M. Szypowska, Kalisz - miasto „Nocy i dni”, „Świat” 1958, nr 33, s. 14-15.

${ }^{22}$ Ludomira Szumska, matka Marii i Heleny była z domu Gałczyńska. 
energicznie zaprzeczyła jakoby miała kogokolwiek informować o pierwowzorach bohaterów występujących w Nocach $i$ dniach, co pozwala domyślać się, że zarzut Heleny: „Zdradzasz wszystkie nazwiska rodziny” musiał być dla pisarki bolesny (list, 27.08.1958), a i sam stosunek do siostry rozpisany był na różne emocje. Nie widać tego co prawda bezpośrednio w korespondencji, trudno zresztą oczekiwać otwartych sądów w listach, ale po raz kolejny przychodzi tu z pomocą dziennik pisarki. Dąbrowska wypowiedziała się o Helenie, pisząc krytycznie o jej zachowaniu, doceniając jej zalety, by na końcu przyznać się przed samą sobą do głębokiego przywiązania, jakim darzy siostrę (dziennik, 24.05.1949). Omijanie w listach kwestii niejednoznacznego stosunku do Heleny jest jednocześnie, obok unikania bezcelowej dyskusji i konfliktu, które zapewne wywołałoby takie zachowanie, świadectwem możliwości gatunku jakim jest epistolografia. Korespondencja Marii Dąbrowskiej to więc, jak każdy zbiór listów, forma niosąca za sobą piętno i myśl nadawcy 23 , dająca sposobność unikania lub podejmowania danych tematów, a przede wszystkim możliwość tworzenia, nawet w sposób nieświadomy, własnego wizerunku. Pisarka kreowała więc obraz siebie poprzez treści, ale także przez kontakt $\mathrm{i}$ komunikację $\mathrm{z}$ innymi ${ }^{24}$. Kwestią zasadniczą pozostał więc problem, na ile jest to kreacja świadoma i do kogo skierowana. Oczywiście, nazwiska adresatek są znane, czy jednak Maria Dąbrowska przewidywała, że korespondencja może stać się lekturą dostępną dla innych? Odpowiedź może sugerować stosunek do pisanych przez większość życia dzienników. Materiał, który powstawał na własne potrzeby (dziennik, 31.12.1936), pisany na bieżąco i mający poufny charakter, w pewnym momencie zaczął podlegać drobnym poprawkom. $\mathrm{Z}$ biegiem czasu zmieniało się do niego nastawienie właścicielki, która rok po wojnie notując: „To nie będzie żadne dzieło, ale może dokument będzie dla czasów oniemiałych" (dziennik, 24.05.1956), mogła zacząć zakładać ujawnienie tego tekstu w przyszłości. Nie bez znaczenia jest to, że rozważała także, za przykładem Gombrowicza, drukowanie na bieżąco części tekstu. Ostatecznie zmianę myślenia potwierdza zapis umieszczony w testamencie z 13 na 14 czerwca 1963 roku, który dopuścił możliwość upublicznienia dzienników 40 lat po śmierci pisarki ${ }^{25}$. W przypadku listów skierowanych do rodziny, stosunek do ujawnienia ich treści

\footnotetext{
${ }^{23}$ S. Skwarczyńska, Teoria listu, Lwów 1937, s. 319.

${ }^{24}$ Więcej na temat komunikacji i kreacji wizerunku nadawcy patrz w: E. Rybicka, Antropologiczne i komunikacyjne aspekty dyskursu epistolograficznego, „Teksty Drugie” 2004, nr 4, s. 50.

${ }^{25}$ T. Drewnowski, Wstęp, w: Dzienniki. T. 1, M. Dąbrowska, Warszawa 1988, s. 5.
} 
mógł wyglądać podobnie, mimo że w tym wypadku pisarka nie miała, ze zrozumiałych względów, możliwości naniesienia jakichkolwiek poprawek. Wydaje się, że tworzenie wizerunku pisarki w listach do siostry i siostrzenicy było procesem spontanicznym i nieplanowanym, a więc niemającym nic wspólnego ze świadomym kreowaniem portretu literatki na potrzeby przyszłych czytelników. Biorąc pod uwagę dobór tematów i sposób relacji narzuconych sobie przez Dąbrowską, można stwierdzić, że autorka Przygód człowieka myślacego pisała bez ukrytego celu, a więc z potrzeby chwili dla siebie i dla rodziny, tworząc wizerunek osoby oddanej, uczynnej, ale jednocześnie, w sposób niewidoczny dla adresata, kontrolującej emocje i ograniczonej zasadami jakie sama sobie narzuciła. Ważnym elementem, który uzupełnia obraz Marii Dąbrowskiej wyłaniający się z listów, jest jej stosunek do przyrody i zwierząt, co ujawniło się szczególnie po zakupieniu domu w podwarszawskim Komorowie. Autorka Nocy $i$ dni zaczęła w tym okresie informować o ulubionym foksterierze (20.12.1962), ogrodzie (list, 6.05.1958) i stanie roślin (22.04.1963). Przyroda pomagała też pisarce opisywać własne emocje. Po śmierci Stanisława Stempowskiego pogoda i krajobraz Szklarskiej Poręby posłuży do skontrastowania piękna z przygnębieniem, z jakim zmagała się Dąbrowska (20.01.1952). Pozwoli jej to też znaleźć pociechę w ostatnich latach życia kiedy: ,... nie ma już dość siły żeby się cieszyć. Cieszyć się trzeba jednak, choćby tym, że jesień cudna i ciepła" (list, 10.10.1958).

W zbiorze pojawiają się także tematy dotyczące spraw zawodowych i prywatnych, przy czym te ostatnie zdecydowanie dominują. Nie znalazły się tu wprawdzie jakiekolwiek zwierzenia natury osobistej, ponieważ tego typu szczerość dotyczyła tylko najbliższych partnerów i przyjaciół Dąbrowskiej ${ }^{26}$, pojawiły się jednak wiadomości o samopoczuciu pisarki. Niemal w każdym liście autorka Przygód człowieka myślacego zdawała mniej lub bardziej szczegółowy raport ze stanu swojego zdrowia, niepokojąc się przy tym o adresatki i korzystając z okazji do wymienienia zalet leków, które zastosowała (list, 21.07.1955). Z biegiem czasu lista chorób wydłużała się, a pisarka skarżyła się na związane z nimi ograniczenia. W jednym z listów kategorycznie odmówiła przyjazdu i spotkania z czytelnikami w Choszcznie, pisząc o słabej kondycji i zdrowiu (list, 2.04.1963), co miało swoje uzasadnienie także w wieku pisarki - Dąbrowska była już wtedy 74-letnią kobietą.

\footnotetext{
${ }^{26}$ E. Głębicka pisze, że pisarka najszczersza była w swej korespondencji z Marianem Dąbrowskim, Stanisławem Stempowskim, Jerzym Stempowskim i Anną Kowalską, zob. E. Głębicka, Dąbrowska (nie)znana..., s. 389.
} 
Zmęczenie, a w późniejszym okresie choroby i podeszły wiek nie odciągnęły jednak autorki Nocy $i$ dni od intensywnych działań, o czym informowała bliskich raportując krótko: „w międzyczasie miałam trochę różnego zawracania głowy”, (list, 10.02.1958) lub: „rzadko pisuję, ale jestem przeciążona intensywną pracą” (list, 11.07.1962) oraz wyraźnie wskazując na sferę zawodową: ,pracy pisarskiej mam po uszy" (list, 11.07.1952). Lapidarne z reguły wiadomości o działalności twórczej zastępowały czasami nieco bardziej rozbudowane informacje, a sam temat pojawiał się w listach spontanicznie (list, 11.07.1952) lub jako odpowiedź na pytanie (list, 11.07.1952). W 1952 roku Maria powiadomiła młodszą siostrę o podpisaniu umowy z Wydawnictwem Czytelnik, w której zobowiązała się oddać na początku stycznia pierwszy tom powieści (list, 11.07.1952). Był to zapewne tekst Przygód człowieka myślacego, nad którym pisarka intensywnie pracowała w latach 1948-1952. W tym okresie powstała wprawdzie część ostatnia powieści, ale po napisaniu partii końcowej Dąbrowska przeszła, mimo braku wyraźnej koncepcji, do opracowywania początkowych rozdziałów ${ }^{27}$. Informację listowną potwierdza późniejszy o 9 dni wpis w dzienniku: „Zaczęłam pisać powieść już na czysto, od razu w czterech egzemplarzach, ale utknęłam na czwartej stronie i dalej ani rusz" (dziennik, 20.07.1952). Problemy twórcze prawdopodobnie przełożyły się na niewywiązanie się z umowy, a pomysł powieści, który narodził się w latach 1938-1939 absorbował pisarkę do końca życia i ostatecznie nie został zrealizowany. Przygody człowieka myślacego wydane zostały dopiero w 1970 roku po opracowaniu przez Ewę Korzeniowską ${ }^{28}$ i 11 lat później w ramach edycji wydzielonych opowiadań przygotowanych przez Tadeusza Drewnowskiego ${ }^{29}$.

Mimo kłopotów z cenzurą, publikacją, która ujrzała światło dzienne za życia pisarki, stał się Dziennik Samuela Pepysa ${ }^{30}$, którego tłumaczeniem Dąbrowska zajmowała się w latach 1945-1948. Przekład gotowy do wydania już w 1949 roku doczekał się publikacji trzy lata później, po interwencji Związku Literatów Polskich $^{31}$. Wprawdzie pisarka nie wspomniała o tych trudnościach w korespon-

${ }^{27}$ T. Drewnowski, Rzecz russowska: o pisarstwie Marii Dąbrowskiej, Kraków 2000, s. $275-276$.

${ }^{28}$ M. Dąbrowska, Przygody czlowieka myślacego, komentarz i przygotowanie tekstu z rękopisów E. Korzeniewska, przedmowa A. Kowalska, Warszawa 1970.

${ }^{29}$ M. Dąbrowska, A teraz wypijmy..., przedmowa T. Drewnowski, Warszawa 1981.

${ }^{30}$ S. Pepys, Dziennik Samuela Pepys, wybór, przekład i przypisy Marii Dąbrowskiej, posł. J. Hochfeld, Warszawa 1952.

${ }^{31}$ T. Drewnowski, Rzecz russowska..., s. 274. 
dencji, ale pod koniec 1953 roku poinformowała siostrę o przygotowywanym drugim, rozszerzonym wydaniu tej pozycji ${ }^{32}$ (list, 25.12.1953).

Kolejne listy przynoszą wiadomości o drobniejszych publikacjach, takich jak artykuł o ogrodach działkowych ${ }^{33}$ (list, 26.03.1959), przedrukowany odczyt o Josephie Conradzie ${ }^{34}$ (list, 11.11.1957) czy opowiadanie Gdzie ty jesteś, Joan$n o ?^{35}$ (list, 11.11.1957). Temat działek nie był czymś niezwykłym w wypadku pisarki, która kwestie społeczne podejmowała przez całe życie, podobnie jak zainteresowanie dorobkiem anglojęzycznego pisarza czytanego od czasów młodości. Utwór ostatni za to stał się nowym rysem w twórczości autorki, która zmierzyła się tu z tematyką wojenną. W liście do siostry Dąbrowska pisząc o opowiadaniu posłużyła się, nie bez przyczyny, terminem „fragment powieści”. Tekst był wydzieloną częścią Przygód człowieka myślacego, a konkretnie jego ostatniej partii dotyczącej powstania warszawskiego ${ }^{36}$. Do wspomnianej powieści pisarka wróciła w swej korespondencji po raz trzeci i zarazem ostatni, tłumacząc perypetie związane z drukowaniem fragmentów w „Przeglądzie Kulturalnym”, który według niej samej „wymógł, wybłagał i wymusił” publikację. Dąbrowska martwiła się tempem druku, ponieważ kolejne odcinki zrównały się szybko z postępami jej prac (tekst praktycznie nie miał początku i wymagał dużo wysiłku ze strony autorki), wykorzystała więc jako pretekst do przerwania współpracy cięcia budżetowe, które dotknęły czasopismo oraz propozycję redakcji sugerującej dokonanie skrótów (list, 8.03.1963). Przedstawiona w liście do Danuty rezygnacja miała jeszcze jedną nieujawnioną przyczynę. Publikowana od października 1961 do stycznia 1963 roku powieść nie cieszyła się zainteresowaniem czytelników i Dąbrowska czując to, skorzystała z nadarzającej się okazji, aby przerwać druk ${ }^{37}$. Nie mogła przewidzieć, że pismo, które stało się niewygodne dla władz, zostanie zamknięte już w czerwcu tego samego roku, co zapewne uwolniłoby ją od kłopotu bez podejmowania niemiłej decyzji ${ }^{38}$.

${ }^{32}$ S. Pepys, Dziennik Samuela Pepysa, wybór, przekład i przypisy Marii Dąbrowskiej, posł. J. Hochfeld, Warszawa 1954.

${ }^{33}$ M. Dąbrowska, Zastanówmy się, „Kurier Polski” 1959, nr 69, s. 3.

${ }^{34}$ M. Dąbrowska, [Joseph Conrad] : 1857-1957, „Nowa Kultura” 1957, nr 49, s. 3.

${ }^{35}$ M. Dąbrowska, Gdzie ty jesteś, Joanno?, „Nowa Kultura” 1957, nr 47, s. 3-4.

${ }^{36}$ T. Drewnowski, Rzecz russowska..., s. 290-291.

37 Tamże, s. 278.

${ }^{38}$ Do cięć budżetowych, które dotknęły pismo doszło w 1959 r., a więc argument wysunięty przez pisarkę wydaje się nie odpowiadać rzeczywistości, tym bardziej, że od początku 
W korespondencji autorka Nocy $i$ dni obok wiadomości o pracy literackiej zamieszczała także krótkie informacje na temat działalności popularyzujących jej twórczość i osobę. Dopytywała Helenę, czy miała okazję słuchać w radiu programu z jej wieczorem autorskim (list, 8.04.1939), pisała o transmisji radiowej z obchodzonego hucznie czterdziestolecia pracy twórczej (list, 20.11.1952), informowała o przyjeździe ekipy „Polskiej Kroniki Filmowej” (list, 22.08.1958), powiadamiała o druku artykułów, sama też wysyłała wycinki prasowe (list, 29.03.1957). W korespondencji najwięcej uwagi poświęciła uroczystościom związanym ze wspomnianym jubileuszem, a szczegółowa relacja, co niezwykłe w wypadku pisarki, wypełniła niemal całą treść (list, 20.11.1952). W tym okresie Maria Dąbrowska wychodziła powoli z izolacji, którą narzuciła sobie po wojnie, nie potrafiąc i nie chcąc egzystować dłużej tylko jako tłumaczka i autorka drobnych artykułów oraz ponownych wydań utworów przedwojennych ${ }^{39}$. Mimo rezerwy i ambiwalentnego stosunku do władz ${ }^{40}$ zaczęła uczestniczyć w pracach Komitetu Wyborczego Frontu Narodowego i opublikowała artykuł $W$ trzynasta rocznice $n a j a z d u^{41}$, będący jej pierwszą publiczną deklaracją w powojennej Polsce. Pisarka zaakceptowała także pomysł ZLP, który wyszedł z propozycją organizacji jubileuszu. Kontynuacją tej zmiany była też publikacja trzech nowych książek: Gwiazda zaranna ${ }^{42}$, Myśli o sprawach i ludziach ${ }^{43}$ oraz Szkice z podróży ${ }^{44}$, a także uhonorowanie pisarki tytułem doktora honoris causa nadanym przez Uniwersytet Warszawski w 1957 roku, co, dziękując za gratulacje, zrelacjonowała w liście do Heleny (list, 29.03.1957).

Doceniana przez władze pisarka prowadziła jednocześnie ożywioną działalność, udzielając pomocy byłym więźniom politycznym, a aktywność ta także

lat 60. nakład wzrastał i w początkach $1963 \mathrm{r}$. liczył prawie 50 tys. egzemplarzy. W tym okresie czasopismo odnoszące się krytycznie do polskiej rzeczywistości miało jednak poważne kłopoty i ostatecznie zostało zamknięte. Więcej o ostatnich latach działalności i przyczynach likwidacji „Przeglądu Kulturalnego” zob. T. Mielczarek, Liberałowie i rewizjoniści: z dziejów „Przeglądu Kulturalnego” (1952-1963), „Kieleckie Studia Bibliologiczne” 2000, t. 5, s. 122-124.

${ }^{39}$ T. Drewnowski, Rzecz russowska..., s. 302-304.

${ }^{40}$ J. Żarnowski, Dzienniki Marii Dąbrowskiej jako źródto wiedzy o historii, „Kultura i Społeczeństwo" 2000, nr 1, s. 39-43.

${ }^{41}$ M. Dąbrowska, W trzynasta rocznicę najazdu, „Nowa Kultura” 1952, nr 36, s. 1.

${ }^{42}$ M. Dąbrowska, Gwiazda zaranna. Warszawa, 1955.

${ }^{43}$ M. Dąbrowska, Myśli o sprawach i ludziach, Warszawa, 1956.

${ }^{44}$ M. Dąbrowska, Szkice z podróży, Warszawa, 1956. 
znalazła swoje odzwierciedlenie w korespondencji do bliskich. Notatka o zasłabnięciu przyjaciela w mieszkaniu Dąbrowskiej pojawiła się w dzienniku 5 marca 1957 roku, a cztery tygodnie później notatkę o kuracji Henryka Józewskiego ${ }^{45}$, który nie miał własnego lokum, a więc przebywał na ul. Niepodległości, otrzymała młodsza siostra (list, 29.03.1957). Pomoc dla amnestionowanych to zresztą nie jedyne wsparcie jakiego udzielała Dąbrowska. List z 1962 roku informujący o śmierci Bronisława Linkego stał się okazją do wspomnień o sześciotygodniowym pobycie jego rodziny przy ul. Polnej w 1946 roku, a słowa poświęcone malarzowi - pretekstem do refleksji o fałszowaniu historii. Pisarka ostrzegła siostrę przed czytaniem nekrologów, w których prawdopodobnie znajdzie słowa o pobycie Linkego podczas wojny w ZSRR i przestrzegła Helenę przed dosłownym traktowaniem tego eufemizmu (list, 15.10.1962).

Sytuacje i wydarzenia opisywane przez pisarkę obnażyły przy okazji mechanizmy działania komunistycznych władz, a także presję jakiej poddane było społeczeństwo. Ustosunkowując się do marzenia siostrzenicy, która chciała przeprowadzić się z Bytowa do Choszczna i pracować tam już nie jako nauczycielka, ale bibliotekarka, napisała:

dzisiaj nie ma dobrowolnych przeniesień człowiek jest przywiązany do swego miejsca pracy i jedynie decyzja władz może stanowić o tym, gdzie i kiedy zostanie przeniesiony (list, 7.03.1951).

Słowa pisarki, która nie musiała powoływać się na powszechnie znany, czy raczej odczuwany w konsekwencji akt prawny ${ }^{46}$, doprecyzowała jeszcze wiele mówiącym komentarzem: „Tak już jest i nic nie pomoże bicie głową o ścianę”, czym potwierdziła tylko bezradność obywateli wobec państwa.

Brak możliwości nie oznaczał jednak zaniechania i porzucenia wszelkich prób zaradzenia sytuacji. Dąbrowska udowodniła to w kolejnym liście, tym razem dotyczącym mieszkania (list, 28.10.1958). Pisarka martwiąc się o młodą parę, siostrzenica właśnie wyszła za mąż, pytała o warunki lokalowe i oferowała pomoc w zdobyciu lokum. Precyzyjnie wyliczyła potrzebne informacje i obiecała

${ }^{45}$ T. Drewnowski [przypis z biogramem H. Józewskiego], w: Dzienniki. T. 2, M. Dąbrowska, Warszawa 1988, s. 183.

${ }^{46}$ Prawne uregulowanie tej sytuacji dała Ustawa z 7.03.1950 r. o zapobieżeniu płynności kadr pracowników w zawodach lub specjalnościach szczególnie ważnych dla gospodarki uspołecznionej (Dz.U. 1950, nr 10, poz. 107). 
napisać list w tej sprawie do odpowiedniej Rady Narodowej i, jeżeli będzie taka potrzeba, do premiera Cyrankiewicza. Mimo rezerwy wobec władzy, pisarka korzystała więc ze swojej pozycji, balansując między dystansem i lojalnością, a jej propozycja wskazuje na powszechny sposób radzenia sobie z realiami życia w Polsce Ludowej.

Wraz z opisem kłopotów jakie przynosiła codzienność, w listach Dąbrowskiej pojawiała się także krytyka. Komentarze nie były tak rozbudowane jak w dziennikach i pojawiały się rzadko, ale pisarka pozwala sobie od czasu do czasu na silne emocje. Podczas choroby Stanisława Hepkego, pisząc o zarzuconych już metodach leczenia, jakim został poddany, komentowała: „Co za barbarzyński kraj!" (list, 28.09.1962). W liście informującym o śmierci Bronisława Linkego donosiła o fałszowaniu biografii malarza przez „lokajskie dusze niektórych dziennikarzy". Nie omieszkała też, tym razem podczas udzielania instrukcji siostrzenicy, z żalem stwierdzić: „Zachowuję dotąd resztkę naiwności i coś takiego nie przychodzi mi do głowy - ale taka jest korekta życia na niewydolne państwowe leczenie!" (list, 2.02.1963).

Krytyczne uwagi, na które pozwalała sobie pisarka, dotyczyły utrudnień jakie niosła za sobą codzienność, natomiast stosunek do kwestii politycznych praktycznie nie pojawiał się w korespondencji. Dąbrowska unikała drażliwych tematów zarówno w listach do mieszkającego za granicą Jerzego Stempowskiego ${ }^{47}$, jak i do osiadłej w północno-zachodniej Polsce rodziny. Postępowanie pisarki, świadomej działań inwigilacyjnych władz (dzienniki, 23.11.1948), było konsekwentne, a przekaz niezwykle ostrożny, o czym świadczy wspomniana już informacja o Henryku Józewskim (list, 29.03.1957). Autorka Nocy i dni powiadamiając o rekonwalescencji przyjaciela podała tylko inicjał imienia byłego więźnia politycznego. Być może adresatka, łącząc fakty, potrafiła rozszyfrować tożsamość rekonwalescenta, który był długoletnim przyjacielem pisarki, natomiast brak danych miał zapewne utrudnić odcyfrowanie personaliów osobom postronnym. Kolejna kwestia, czyli powstanie węgierskie, zostało omówione równie oszczędnie. Dąbrowska wskazała na „tragiczny los Węgier”, który wywołał w niej nadzieję i przerażenie, a ,cały ten wielki rwetes historyczny” oderwał ją od zajęć, dlatego opuściła Warszawę, ,,aby intensywną pracą nadrobić zaległości”(list, 20.11.1956). Niepokój i strach, które ujawniła pisarka, został więc natychmiast powściągnięty,

\footnotetext{
${ }^{47}$ A.S. Kowalczyk, Habent sua fata libelli..., w: Listy 1923-1953, M. Dąbrowska, J. Stempowski, Warszawa 2010, s. 13.
} 
a ona sama przeszła do omawiania problemów prywatnych. Dopiero siedem lat później pozwoliła sobie, prawdopodobnie ze względu na solidarność ze środowiskiem literackim, skomentować stosunek władz do twórców: „partia nie cierpi pisarzy - nawet niektórych partyjnych, o ile nie są dość karni”, a w formie ostrzeżenia podkreśliła: „to tylko dla Ciebie oczywiście”(list, 8.03.1963). Pisarka nie przypuszczała wtedy, że rok później sama doświadczy nieprzyjemności, narażając się władzy. Podpisując w marcu 1964 roku List 34 nie doznała wprawdzie bezpośrednich represji jakie spadły na większość sygnatariuszy tego dokumentu - władze starały się w ten sposób skłócić grupę ${ }^{48}$ - miała jednak okazję doświadczyć kampanii propagandowej przeciwko twórcom, którzy ośmielili się przedłożyć pismo. Wzięła też udział w Walnym Zebraniu Oddziału Warszawskiego ZLP, gdzie 12 czerwca 1964 roku przemówiła w imieniu sygnatariuszy i zaprzeczyła jakoby celem listu było oczernienie Polski za granicą. Nieprzyjemne wydarzenia znalazły odzwierciedlenie w korespondencji z Danutą, ale i tym razem komentarz Dąbrowskiej był szalenie enigmatyczny:

dałam się wciągnąć w sprawy środowiska literackiego, a chyba się to jeszcze nie skończyło i są to rzeczy nad wyraz nieprzyjemne, zwłaszcza przy naszej polskiej skłonności do obmowy i plotkarstwa (list, 15.05.1964).

Obok nielicznych wątków związanych z polityką w listach można też natknąć się na treści opisujące zmiany społeczne. Palącą kwestią był brak służby domowej, przy tym informacje o potrzebie godzenia zajęć codziennych z pracą zawodową podczas urlopu gospodyni nie stanowił jedynego problemem autorki Nocy i dni (list, 25. 07.1952). Przebywając w Komorowie, Dąbrowska zetknęła się ze zjawiskiem masowego opuszczania wsi przez kobiety i nie mogąc znaleźć stosownej kandydatki do pracy w domu pisała: „życie nie jest jeszcze tak urządzone, aby pracując można się było bez pomocy domowej obejść". Bazując na swoich doświadczeniach, dodawała dalej: „mężczyźni pisarze mają przynajmniej żony, które im prowadzą gospodarstwo" (list, 16.12.1960). Pisarka dostrzegała więc zanikanie pewnej profesji, ale jej reakcja ograniczyła się w tym wypadku tylko do zazdrości wobec płci przeciwnej, której sytuację potraktowała jako oczywistą, a związku z tym stałą i, póki co, dla niej nieosiągalną.

${ }^{48}$ J. Eisler, List 34, Warszawa 1993, s. 54-57. 


\section{Podsumowanie}

Korespondencja Marii Dąbrowskiej to materiał bogaty w informacje prywatne, jest więc przede wszystkim źródłem wiedzy o codzienności pisarki, rodziny Hepków oraz, pośrednio, o realiach życia Polski powojennej. Autorka Nocy $i$ dni dzieląc się wiadomościami natury zawodowej, komentując wydarzenia polityczne i dostrzegając zmiany społeczne, uczyniła to jednak w sposób zdawkowy i oszczędny. Powodem tak rozłożonych akcentów była ostrożność, jaka musiała cechować Dąbrowską, świadomą działań perlustracyjnych, ale najważniejszą przyczyną tej postawy był stosunek nadawczyni do adresatek.

Pisarka, na co wskazują także przytoczone listy, nigdy nie traktowała młodszej siostry i siostrzenicy jako poważnych partnerek do rozmów. Dąbrowska chętnie dzieliła się w swych listach do przyjaciół i bliskich refleksjami natury artystycznej czy intelektualnej, jednak konsekwentnie nie podejmowała takiego dyskursu z Heleną i Danutą. Korespondencja rodzinna nie służyła więc w tym wypadku wymianie refleksji czy emocjonalnym wynurzeniom, ale podtrzymaniu więzi rodzinnych.

Kolejna kwestia, czyli autokreacja pisarki nie stała się świadomym narzędziem budowania własnego wizerunku na potrzeby przyszłych czytelników. Autorka Przygód czlowieka myślacego pisała dla siebie i rodziny w sposób nieplanowany, związany tylko obowiązującym konwenansem i dobrymi manierami. Wprawdzie nie mogła i nie chciała wypowiadać się w listach tak szczerze i otwarcie jak w swoich codziennych zapiskach, ale smutek, nieudawane oburzenie czy hamowana irytacja pojawiające się z rzadka w korespondencji, stały się dalekim, ale jednak żywym odbiciem komentarzy pisanych pod wpływem emocji i na bieżąco w dziennikach.

Brak listów z okresu przedwojennego pozbawiła analizowany materiał szerszego kontekstu i możliwości obserwowania zmian, jakie w sposobie komunikacji narzucił upływający czas. Korespondencja z Heleną trwająca ponad pół wieku oraz około 40-letnia wymiana listów z Danutą mogłaby być pełniejszym źródłem wiedzy, a co za tym idzie uzupełnieniem wizerunku relacji rodzinnych. Być może poszerzyłaby też spektrum zagadnień, które ze względu na perlustrację, zostały pominięte. Wypada żałować, że wspomniana korespondencja nie zachowała się, ale jednocześnie docenić wysiłki adresatek, dzięki którym pozostałe listy przetrwały i trafiły do biblioteki. 


\section{Bibliografia}

\section{Źródła}

Akcesje. Nr 2, lata 1998-2005, Książnica Pomorska, Dział Zbiorów Specjalnych, Oddział Starych Druków i Rękopisów, Sekcja Rękopisów.

Dąbrowska M., Dzienniki, wybór, wstęp i przypisy T. Drewnowski, Warszawa 1988.

Dąbrowska M., Dzienniki 1914-1965 w 13 tomach, oprac. T. Drewnowski, Warszawa 2009.

Fotografie rodzinne ze zbiorów Danuty Hepke-Kelch [rękopis], Książnica Pomorska w Szczecinie, nr sygn. Rkps988.

Korespondencja Marii Dąbrowskiej do Heleny Hepke i Danuty Hepke-Kelch [rękopis], KP, nr sygn. Rkps986.

Korespondencja osób różnych do Heleny Hepke i Danuty Hepke-Kelch [rękopis], KP, nr sygn. Rkps987.

Katalog rękopisów Muzeum Literatury im. Adama Mickiewicza w Warszawie. T. 5, Sygnatury 2001-2180: archiwa Marii Dabrowskiej, Anny Kowalskiej, Stanisława Stempowskiego, oprac., red. S. Kordaczuk, Warszawa 2017.

Maria Dąbrowska: wspomnienia siostrzenicy [dokument elektroniczny], KP, nr sygn. MW131.

Korespondencja Marii Dąbrowskiej do Heleny Hepke i Danuty Hepke-Kelch [dokument elektroniczny], KP, nr sygn. MW132.

Ustawa z 7.03.1950 r. o zapobieżeniu płynności kadr pracowników w zawodach lub specjalnościach szczególnie ważnych dla gospodarki uspołecznionej (Dz.U. 1950 r., nr 10, poz. 1070 .

\section{Opracowania}

Cysewski K., Teoretyczne i metodologiczne problemy badań nad epistolografia, „Pamiętnik Literacki” 1997, nr 1.

Drewnowski T., Rzecz russowska: o pisarstwie Marii Dąbrowskiej, Kraków 2000.

Eisler J., List 34, Warszawa 1993.

Głębicka E., Dąbrowska (nie)znana: szkice, Warszawa 2013.

Jabłecki T.W., Danuta Hepke-Kelch: z cyklu zastużeni ludzie Choszczna, „Bibliotekarz Zachodniopomorski" 1997, nr 1-2.

Kelch D., Wspomnienia siostrzenicy Marii Dąbrowskiej, Kalisz 2013.

Kościuczuk A., Danuta Maria Kelch z domu Hepke, „Bibliotekarz Zachodniopomorski” 2013, $\mathrm{nr} 4$.

Kowalczyk A.S., Habent sua fata libelli, w: Listy 1923-1953, M. Dąbrowska, J. Stempowski, Warszawa 2010.

Krawiec T., Siostrzenica stynnej Marii, „Gazeta Lubuska” 2003, nr 219. 
Lipińska E., Tu żyja potomkowie Niechciców, „Głos Szczeciński” 2002, nr 296.

Mielczarek T., Liberałowie i rewizjoniści: z dziejów „Przeglądu Kulturalnego” (19521963), „Kieleckie Studia Bibliologiczne” 2000, t. 5.

Pepys S., Dziennik Samuela Pepysa, wybór, przekład i przypisy M. Dąbrowskiej, posł. J. Hochfeld, Warszawa 1952.

Rybicka E., Antropologiczne i komunikacyjne aspekty dyskursu epistolograficznego, „Teksty Drugie” 2004, nr 4.

Szypowska M., Kalisz - miasto „,Nocy i dni”, „Świat” 1958, nr 33.

Skwarczyńska S., Teoria listu, Lwów 1937.

Żarnowski J., Dzienniki Marii Dąbrowskiej jako źródło wiedzy o historii, „Kultura i Społeczeństwo" 2000, nr 1.

\begin{abstract}
Abstrakt
W artykule zaprezentowano nieanalizowane dotychczas listy Marii Dąbrowskiej do siostry, Heleny Hepke i siostrzenicy - Danuty Hepke-Kelch, z lat 1934-1965, przechowywane w Książnicy Pomorskiej. Autorka wzięła pod uwagę sylwetki adresatek, charakterystykę formalną i zawartość rzeczową korespondencji. Cechy zewnętrzne to problem niezachowanej części listów, a także ogólny opis Archiwum Heleny Hepke-Kelch i zdigitalizowanej kolekcji dokumentów - własności Miejskiej Biblioteki Publicznej w Choszcznie, będącej integralną częścią zbioru. W rozdziale poświęconym zawartości rzeczowej omówiono charakterystyczne cechy form epistolograficznych stosowanych przez Marię Dąbrowską i, przede wszystkim, tematykę podejmowaną przez pisarkę w listach. Zasygnalizowano problem autokreacji, a także zagadnienie zmian społecznych w Polsce w latach 50. i 60. XX wieku. Tematykę listów omówiono dzięki metodzie porównawczej, a głównym materiałem analizy stały się, obok korespondencji, Dzienniki pisarki opublikowane bez cenzorskich skrótów w 2009 roku.
\end{abstract}

\title{
Family correspondence of Maria Dąrowska in the collections of THE Pomeranian Library
}

\begin{abstract}
The article presents the letters written in the years 1934-1965 by Maria Dąbrowska to her sister, Helena Hepke, and her niece, Danuta Hepke-Kelch, never analysed before and kept in the Pomeranian Library. The article describes the addressees and contains an analysis of the form and contents of the letters. Among the external features the following
\end{abstract}


factors may be mentioned: the fact that part of the letters have not been found, the general description Archiwum Heleny Hepke-Kelch and the digitalised group of the documents that are the property of the Public Library in Choszczno and an integral part of the whole collection. In the chapter devoted to the contents there is a short characterisation of the features of the epistolographic forms used by Maria Dąbrowska and of the topics the writer took up in her letters. The article mentions the problem of self-creation and the question of social changes that took place in Poland in the 1950s and 1960s. The topics of the letters have been discussed using comparative methods, and the main material for the analysis has been, in addition to the correspondence, Dzienniki (Diaries) written by Maria Dąbrowska and published in 2009 without any censor's changes. 